\title{
TEACHING MATERIALS DEVELOPMENT DESCRIPTION ORIENTED OF GUIDED WRITING STRATEGY FOR GRADE IV STUDENTS ELEMENTARY SCHOOL
}

\author{
Afriyal Is ${ }^{1}$, Taufina Taufik ${ }^{2}$, Ramalis Hakim ${ }^{3}$, Darnis Arief ${ }^{4}$, Desyandri ${ }^{5}$ \\ ${ }^{1}$ SDN 06 Koto Gadang, Kabupaten Solok, Indonesia \\ 2,3,4,5 Universitas Negeri Padang, Padang, Indonesia \\ ${ }^{1}$ al.afriyal.islami@gmail.com, ${ }^{2}$ taufina@fib.unp.ac.id, ${ }^{3}$ ramalishakim@gmail.com, ${ }^{4}$ nis.darnis@gmail.com, \\ ${ }^{5}$ desyandri@fip.unp.ac.id
}

\section{ABSTRACT}

The purpose of this teaching material development is to produce a teaching material that is a valid, practical, and effective oriented description of Guided Writing. This type of development study with model 4-D models consisting of definition define, design, development, and dissemination (disseminate). Research Data from validity tests is obtained through RPP validation sheets and teaching materials. Practicality Data is collected through an observation sheet of RPP implementation and a response to the teacher and student responses. The effectiveness of students 'learning activities and processes in the form of character assessment and student writing skills. Collected Data is analyzed descriptively. Results of the study of the validity of the instrument teaching materials obtained 98.04 categorized very valid. The results of observations, polls, and interviews with teachers also stated that this teaching material is practical. The results of the effectiveness of teaching materials based on trials and the dissemination of skills assessment of the students 'descriptions for the assessment of the process skills have also been in excellent categories, and the results of the results from the 95.19 trial acquisition in the dissemination process obtained the 95.75 value. The acquisition shows that the teaching materials of a guided strategy-oriented description of the class IV SD that has been produced can be declared valid, practical, and effective.

Keywords: writing a description and guided writing strategy

\section{PENGEMBANGAN BAHAN AJAR MENULIS DESKRIPSI BERORIENTASI STRATEGI GUIDED WRITING UNTUK SISWA KELAS IV SEKOLAH DASAR}

\begin{abstract}
ABSTRAK
Tujuan pengembangan bahan ajar ini adalah untuk menghasilkan bahan ajar menulis deskripsi berorientasi Strategi Guided Writing yang valid, praktis, dan efektif. Jenis penelitian pengembangan dengan model model 4-D yang terdiri dari tahap pendefinisian (define), perancangan (design), pengembangan (development), dan penyebaran (disseminate). Data penelitian dari uji validitas diperoleh melalui lembar validasi RPP dan bahan ajar. Data kepraktisan dikumpul melalui lembar observasi keterlaksanaan RPP dan angket respon guru serta siswa. Keefektifan dilihat dari aktivitas dan proses hasil belajar siswa berupa penilaian karakter dan keterampilan menulis siswa. Data yang terkumpul dianalisis secara deskriptif. Hasil penelitian dari validitas instrumen bahan ajar memperoleh nilai 98.04 dikategorikan sangat valid. Hasil observasi, angket, dan wawancara dengan guru juga menyatakan bahwa bahan ajar ini praktis. Hasil efektifitas bahan ajar berdasarkan uji coba dan penyebaran penilaian keterampilan menulis deskripsi siswa untuk penilaian keterampilan proses juga telah berada pada kategori sangat baik, dan didapatkan hasil mingkat dari hasil perolehan uji coba 95.19 pada proses penyebaran memperoleh nilai 95.75. perolehan tersebut menunjukan bahawa bahan ajar menulis deskripsi berorientasi strategi guided writing untuk kelas IV SD yang telah dihasilkan dapat dinyatakan valid, praktis, dan efektif
\end{abstract}

Kata Kunci: menulis deskripsi dan strategi guided writing

\begin{tabular}{|c|c|c|}
\hline Submitted & Accepted & Published \\
\hline 18 Juli 2020 & 10 September 2020 & 26 September 2020 \\
\hline
\end{tabular}

\begin{tabular}{|l|c|c|c|}
\hline Citation & $:$ & $\begin{array}{r}\text { Is, A., Taufik, T., Hakim, R., Arief, D., \& Desyandri. (2020). Teaching Materials Development Description Oriented Of } \\
\text { Guided Writing Strategy For Grade IV Students Elementary School. Jurnal PAJAR (Pendidikan dan } \\
\text { Pengajaran), 4(5), 999-1006. DOI : http://dx.doi.org/10.33578/pjr.v4i5.8113. }\end{array}$ \\
\hline
\end{tabular}

\section{PENDAHULUAN}

Sumber belajar bagi siswa sangat penting. Dikarenakan dengan diberikan media atau sumber belajar yang menarik maka siswa akan memiliki ketertarikkan untuk mengikuti proses pembelajaran. Pembelajaran bahasa Indonesia terdiri dari empat keterampilan yang harus dicapai yaitu keterampilan menyimak, berbicara, membaca, dan menulis. keterampilan menulis siswa kelas IV sekolah dasar sangat menarik untuk diteliti karena dalam keterampilan menulis siwa 
diajarkan bagaimana cara menulis cerita baik dalam bentuk fiksi maupun non fiksi. Latar belakang penelitian ini penulis lakukan yaitu berdasarkan observasi dan pengamatan pada tahun pelajaran sebelumnya penulis terdapat beberapa permasalahan yang penulis temukan diantaranya bahan ajar yang digunakan kurang sesuai dengan tuntutan ketercapaian kurikulum, bahan ajar yang digunakan kurang sesuai dengan tujuan pembelajaran, sehingga apa yang diharapkan dari sebuah proses pembelajaran tidak tercapai secara efektif, bahan ajar yang digunakan tidak memuat tahap-tahap menulis yang benar, sehingga peserta didik kesulitan untuk menulis, bahan ajar tidak menggunakan strategi/ metode/ model menulis yang tepat, sehingga peserta didik kesulitan untuk menulis, selain itu kurangnya pemahaman dan kreativitas guru dalam mengembangkan bahan ajar. Berdasarkan fenomena yang terjadi maka penulis mengembangkan suah bahan ajar yang sesuai dengan kebutuhan dan karakter siswa kelas IV sekolah dasar yangmana didalamnya terdapat tahapan-tahapan menulis secara sistematis sehingga memudahkan siswa untuk belajar dan mengembangkan kemampuan menulisnya.

Keterampilan menulis yang dikemukakan oleh (Arief, 2014; Chandra., Arief, Kharisma, Habibi, \& Suriani, 2020; Dahliana, Taufina, Nasrul, \& Sukandar, 2019; Fauziah, Sulaeman, \& Chandra, 2020; Taufina, 2015) menjelaskan bahwa di dalam kemampuan menulis seorang siswa harus mampu membaca beberapa wacana sebagai ide untuk menciptakan dan mengembangkan sebuah opini atau cerita yang menarik untuk ditulis. Keterampilan itu adalah keterampilan membaca, karena kedua keterampilan ini memiliki satu kesatuan yang saling berkaitan sehingga siswa yang mampu menulis pastilah ia memiliki keterampilan membaca yang sangat bagus. Karena dengan membaca siswa tersebut memiliki kosa kata atau ide-ide yang menarik untuk ditulis sehingga menjadi teks/wacana yang menarik.

Keterampilan menulis yang akan dikembangkan atau diajarkan pada siswa kelas IV sekolah dasar ini yaitu keterampilan menulis deskripsi. Kegiatan menulis deskripsi yaitu kegiatan yang menceritakan proses suatu kejadian atau peristiwa secara sistematis. Sejalan dengan pendapat (Taufina., 2016) yang menjelaskan bahwa menulis deskripsi adalah menulis dengan menceritakan keadaan atau kejadian yang sesuai dengan aslinya sehingga pembeca dapat merasa apa yang dirasakan oleh penulis.

Selanjutnya untuk mengembangkan bahan ajar ini penulis mendesain proses pembelajaran dengan menggunakan strategi guided writing. Strategi guided writing merupakan salah satu strategi yang dikembangkan dari whole language, pembelajaran dengan strategi guided writing ini pernah digunakan untuk menulis narasi. Dimana menurut (Arief, 2018) guided writing merupakan strategi pembelajaran menulis yang dilakukan guru dalam membimbing siswa untuk menemukan sesuatu yang akan ditulis sehingga kemampuan menulis siswa meningkat. Sejalan dengan pendapat (Yunismar, 2019) yang mengemukakan bahwa dalam kegiatan menulis terbimbing guru berperan sebagai fasilitator, membantu siswa menemukan apa yang ingin ditulis dan bagaimana menuliskannya sehingga dapat menjadi sebuah karangan yang menarik dan berurutan. Pengembangan produk berupa bahan ajar yaitu dimulai dari pendefenisian yaitu menganalisis kebutuhan siswa, perancangan yaitu merancang bahan ajar dengan memilih standar kompetensi dan kompetensi selanjutnya memilih strategi yang sesuai dengan dengan kebutuhan siswa yaitu startegi guided writing. Rencana pelaksanaan pembelajaran (RPP) dirancang sesuai dengan langkah-langkah membaca deskripsi yang berorientasi pada strategi guided writing tergambar pada bahan ajar. Pengembangan yaitu melakukan validasi oleh ahli untuk diujicobakan, setelah semua dinyatakan valid bahan ajar dapat dilakukan penyebaran untuk mengetahui efektifitas bahan ajar yang dikembangkan

\section{KAJIAN TEORETIS}

Kegiatan menulis yang benar ialah melewati tahapan-tahapan pramenulis, saat menulis, dan pasca menulis. Sehingga kegiatan menulis yang dilakukan siswa sistematis. 
Menurut (Taufina, 2015; Yunismar, 2019) tahapan dari proses menulis sebagai berikut: 1) pramenulis yaitu tahap persiapan. Pada tahap ini seorang penulis melakukan berbagai kegiatan, misalnya menemukan ide, gagasan, menentukan judul tulisan, memilih bentuk atau jenis tulisan, membuat kerangka dan mengumpulkan bahanbahan. 2) saat menulis merupakan tahap menulis dilakukan dengan menjabarkan ide ke dalam bentuk tulisan. Ide-ide itu dituangkan dalam bentuk kalimat dan paragraf. Selanjutnya, paragraf-paragraf itu dirangkaikan menjadi suatu tulisan yang utuh. Selanjutnya, 3) pascamenulis terdiri atas tiga langkah, yaitu: (a) merevisi atau mengubah, (b) mengedit, dan (c) menyajikan atau mempublikasikan tulisan.

Menurut (Dalman, 2015) karangan deskripsi memiliki ciri-ciri antara lain: memperlihatkan detail tentang objek; memberi pengaruh dan membentuk imajinasi pembaca; pilihan katanya mengunggah; dan memaparkan sesuatu yang didengar, dilihat serta dirasakan.

Pembelajaran bahasa merupakan pembelajaran yang mencangkup seluruh kegiatan pembelajaran. menulis merupakan salah satu keterampilan yang membantu siswa dalam mengambangkan ide-idenya dalam bentuk tulis. Ide-ide yang dikembangkan siswa dalam mentuk tulis ini akan menjadi sebuah karya yang dapat berpengaruh positif dalam kehidupan siswa. Menurut (Habibi \& Chandra, 2018) menulis merupakan sebuah bakat yang tumbuh didalam diri siswa itu sendiri. Siswa yang berbakat dapat menjadikan karya tulisnya sebagai hobbi bahkan profesi.

Strategi menulis terbimbing atau guided writing adalah suatu strategi untuk mengembangkan keterampilan menulis dan menggunakan keterampilan menulis untuk meningkatkan pengajaran. Strategi guided writing atau menulis terbimbing merupakan salah satu strategi pembelajaran menulis yang dapat diterapkan guru bahasa (Abbas, 2006; Arief, 2018).

\section{METODE PENELITIAN}

Model pengembangan yang digunakan pada penelitian ini adalah model 4-D. (four $D$ models) sebagaimana dikemukakan (Fauziah et al., 2020) model ini terdiri dari empat tahap yaitu pendefenisian. (Define) yaitu mendefenisikan tentang kebutuhan sumber belajar serta kebutuhan siswa, perancangan (Design) proses pembelajaran yang menarik bagi siswa, pengembangan (Development) melakukan uji kelayakan oleh validator ahli dan praktisi yang mengampuni bahan ajar dan keterampilan menulis, dan penyebaran (Disseminate) melakukan uji coba atas produk yang telah dinyatakan valid oleh validator. Penelitian dilaksanakan di SDN 21 Gantung Ciri dan 04 Koto Hilalang. Penelitian dilaksanakan 17 Juni - 5 Juli. Dengan mengunakan intrumeninstrumen yang telah divalidasi oleh validator ahli dan praktisi berupa instrumen validasi RPP, Validasi Bahan Ajar, Keterlaksanaan RPP, respon guru dan peserta didik terhadap praktikalitas bahan ajar, aktivitas peserta didik, dan observasi penggunaan bahan ajar.

\section{HASIL DAN PEMBAHASAN}

Hasil penelitian ini dimulai dengan proses validasi intrumen yang akan digunkan dalam proses pengembangan bahan ajar menulis deskripsi berorientasi strategi guided writing dimana hasil yang diperoleh. Pada tahap validasi instrumen pada tahap pengembangan mendesain produk yang akan dikembangkan adalah sebagai berikut.

Tabel 1. Hasil Penilaian Instrumen oleh Validator Ahli

\begin{tabular}{clccccc}
\hline No & Instrumen & \multicolumn{3}{c}{$\begin{array}{c}\text { Jumlah Skor Penilaian } \\
\text { dari Validator }\end{array}$} & \multirow{2}{*}{$\begin{array}{c}\text { Rata- } \\
\text { rata } \\
(\%)\end{array}$} & Kategori \\
\cline { 3 - 5 } & & V1 & V2 & V3 & & \\
\hline 1 & Validasi RPP & 85.71 & 100 & 100 & 95.24 & Sangat Valid \\
2 & Validasi bahan ajar & 100 & 100 & 100 & 100 & Sangat Valid \\
\hline
\end{tabular}


Jurnal PAJAR (Pendidikan dan Pengajaran)

Volume 4 Nomor 4 Juli 2020 | ISSN Cetak : 2580 - 8435 | ISSN Online : 2614 - 1337

DOI : http://dx.doi.org/10.33578/pjr.v4i5.8010

$\begin{array}{lllllll}3 & \text { Lembar keterlaksanaan RPP } & 92.86 & 100 & 100 & 91.5 & \begin{array}{l}\text { Sangat Valid } \\ 4\end{array} \\ \begin{array}{l}\text { Lembar respon guru terhadap } \\ \text { praktikalitas bahan ajar }\end{array} & 96.43 & 100 & 92.86 & 97.2 & \text { Sangat Valid } \\ 5 \quad \begin{array}{l}\text { Lembar respon peserta didik terhadap } \\ \text { praktikalitas bahan ajar }\end{array} & 92.86 & 100 & 89.29 & 94.05 & \text { Sangat Valid } \\ 6 \quad \begin{array}{l}\text { Lembar observasi pengguna-an bahan } \\ \text { ajar }\end{array} & 92.86 & 100 & 100 & 97.62 & \text { Sangat Valid } \\ 7 & \begin{array}{l}\text { Lembar observai aktivitas peserta } \\ \text { didik }\end{array} & 100 & 100 & 100 & 100 & \text { Sangat Valid } \\ \end{array}$

Tabel 1 menunjukan bahwa instrumen yang didesain telah di validasi dan dinyatakan sangat valid sehingga dapat digunakan pada proses pengembangan. Selanjutnya, setelah melakukan proses validasi instrumen maka akan dilakukan proses validasi rencana pelaksanaan pembelajaran (RPP) sebelum diujicobakan atau dilakukan penyebaran. Berikut ini rekap kasih validasi RPP dan bahan ajar yang dilakukan validator ahli dan praktisi.

Tabel 2. Validasi RPP Menulis Deskripsi Berorientasi Strategi Guide Writing

\begin{tabular}{|c|c|c|c|c|c|c|c|}
\hline \multirow[t]{2}{*}{$\mathbf{N}$} & Aspek yang Dinilai & \multicolumn{4}{|c|}{$\begin{array}{l}\text { Nilai } \\
\text { Validasi }\end{array}$} & \multirow{2}{*}{$\begin{array}{l}\text { Rata- } \\
\text { rata } \\
(\%)\end{array}$} & \multirow[t]{2}{*}{ Kategori } \\
\hline & & V1 & V2 & V3 & V4 & & \\
\hline 1 & Aspek Identitas & 100 & 100 & 100 & 100 & 100 & Sangat Valid \\
\hline 2 & Aspek Perumusan Indikator & 100 & 100 & 100 & 100 & 100 & Sangat Valid \\
\hline 3 & $\begin{array}{l}\text { Aspek Perumusan Tujuan } \\
\text { Pembelajaran }\end{array}$ & $\begin{array}{c}91.6 \\
7\end{array}$ & 100 & 100 & 100 & 97.92 & Sangat Valid \\
\hline 4 & $\begin{array}{l}\text { Aspek Pemilihan } \\
\text { Pembelajaran }\end{array}$ & 100 & 100 & 100 & 100 & 100 & Sangat Valid \\
\hline 5 & $\begin{array}{l}\text { Aspek Pemilihan Media dan } \\
\text { Sumber Belajar }\end{array}$ & $\begin{array}{c}83.3 \\
3\end{array}$ & 75 & 100 & 100 & 89.58 & Valid \\
\hline 6 & $\begin{array}{l}\text { Aspek Penyusunan Kegiatan } \\
\text { Pembelajaran }\end{array}$ & 95 & 100 & 100 & 100 & 98.75 & Sangat Valid \\
\hline 7 & Aspek Penilaian & 100 & 100 & 100 & 100 & 100 & Sangat Valid \\
\hline & Rata-rata & $\begin{array}{c}95.7 \\
1\end{array}$ & 96.43 & 100 & 100 & 98.04 & Sangat Valid \\
\hline
\end{tabular}

Tabel 2 menunjukan bahawa RPP yang didesain dan dilakukan validasi menyatakan bahwa RPP dinyatakan sangat valid. Sehingga RPP dapat digunakan pada proses ujicoba dan penyebaran. Sebagai pendukung proses pengajaran produk utama penelitian ini adalah bahan ajar.
Untuk itu, bahan ajar dirancang oleh peneliti berorientasi strategi guided writing untuk menulis deskripsi yang dikembangkan melalui proses validasi oleh ahli terhadap 4 aspek yaitu Isi, kebahasaan dan Penyajian serta kegrafikaan. berikut hasil validasi bahan ajar. 
Tabel 3. Validasi Bahan Ajar

\begin{tabular}{llcl}
\hline No & \multicolumn{1}{c}{ Aspek yang Dinilai } & Nilai & Kategori \\
& & & \\
\hline A. Aalidasi & \\
B. Aspek Isi & Aspek Kebahasaan dan penyajian & $98.71 \%$ & Sangat Valid \\
C. Aspek Kegrafikaan & $98.61 \%$ & Sangat Valid \\
& Rata-rata & $97.92 \%$ & Sangat Valid \\
& & $\mathbf{9 8 . 4 2 \%}$ & Sangat Valid \\
\hline
\end{tabular}

Sebagaimana tabel 2 dan tabel 3 diperoleh hasil validasi dengan kategori sangat valid maka bahan ajar akan diujicobakan pada siswa kelas IV sekolah dasar dengan mengikuti tahapan dari menulis berorientasi strategi guided writing yang telah dikembangkan baik pada rencana pelaksanaan pembeajaran dan bahan ajar yang digunakan.

Proses pembelajaran yang dilakukan meliputi aspek penilaian berdasarkan pada indikator penilaian menulis deskripsi. Berikut ini hasil dari proses menulis deskripsi pada tahapan ujicoba.

Tabel 4. Hasil Penilaian Proses Keterampilan Menulis Deskripsi Ujicoba

\begin{tabular}{|c|c|c|c|c|c|c|}
\hline \multirow[t]{2}{*}{ No } & \multirow[t]{2}{*}{ Proses Menulis Deskripsi } & \multicolumn{3}{|c|}{ Nilai Rata-rata Kelas (\%) } & \multirow{2}{*}{$\begin{array}{l}\text { Rata- } \\
\text { rata }\end{array}$} & \multirow[t]{2}{*}{ Kategori } \\
\hline & & Pertemuan 1 & Pertemuan 2 & Pertemuan 3 & & \\
\hline & Pra menulis & & & & & \\
\hline 1 & $\begin{array}{l}\text { Kemampuan siswa menentukan topik } \\
\text { berdasarkan pengalaman }\end{array}$ & 97.78 & 97.78 & 100 & 98.52 & $\begin{array}{l}\text { Sangat } \\
\text { Tinggi }\end{array}$ \\
\hline 2 & $\begin{array}{l}\text { Kemampuan siswa mengumpul-kan } \\
\text { kata-kata atau frasa sesuai topik }\end{array}$ & 97.78 & 97.78 & 100 & 98.52 & $\begin{array}{l}\text { Sangat } \\
\text { Tinggi }\end{array}$ \\
\hline & Saat menulis & & & & & \\
\hline 3 & $\begin{array}{l}\text { Kemampuan Siswa mengem-bangkan } \\
\text { kerangka karangan }\end{array}$ & 91.11 & 86.67 & 91.11 & 89.63 & $\begin{array}{l}\text { Sangat } \\
\text { Tinggi }\end{array}$ \\
\hline 4 & $\begin{array}{l}\text { Kemampuan Siswa menyususn dan } \\
\text { mengolah kata-kata atau frasa menjadi } \\
\text { sebuah karangan } \\
\text { Pascamenulis }\end{array}$ & 95.56 & 95.56 & 97.78 & 96.3 & $\begin{array}{l}\text { Sangat } \\
\text { Tinggi }\end{array}$ \\
\hline 5 & $\begin{array}{l}\text { Kemampuan siswa mengoreksi dan } \\
\text { memperbaiki tulisannya dalam } \\
\text { pengunaan ejaan, huruf kapital dan } \\
\text { tanda titik }\end{array}$ & 93.33 & 97.78 & 95.56 & 95.56 & $\begin{array}{l}\text { Sangat } \\
\text { Tinggi }\end{array}$ \\
\hline 6 & Kemampuan siswa membaca karangan & 93.33 & 93.33 & 91.11 & 92.59 & $\begin{array}{l}\text { Sangat } \\
\text { Tinggi }\end{array}$ \\
\hline & Rata-rata & 94.81 & 94.81 & 95.93 & 95.19 & $\begin{array}{r}\text { Sangat } \\
\text { Tinggi }\end{array}$ \\
\hline
\end{tabular}

Tabel 4 menunjukkan bahwa pertemuan ke-1, ke-2 dan ke-3 pada sekolah uji coba penilaian proses menulis deskripsi secara keseluruhan memiliki rata-rata persentase $95.19 \%$ dengan kategori sangat tinggi. Artinya, ketika proses pebelajaran berlangsung, aktivitas peserta didik sangat baik dalam memahami dan menggunakan bahan ajar yang dikembangkan. 
Selanjutnya pada sekolah penyebaran hasilnya menunjukan peningkatan yang baik.
Berikut ini penilaian proses pada sekolah penyebaran.

Tabel 4. Hasil Penilaian Proses Keterampilan Menulis Deskripsi Penyebaran

\begin{tabular}{|c|c|c|c|c|c|c|}
\hline \multirow[t]{2}{*}{ No } & \multirow[t]{2}{*}{ Proses Menulis Deskripsi } & \multicolumn{3}{|c|}{ Nilai Rata-rata Kelas (\%) } & \multirow{2}{*}{$\begin{array}{c}\text { Rata-rata } \\
\%\end{array}$} & \multirow[t]{2}{*}{ Kategori } \\
\hline & & Pertemuan 1 & Pertemuan 2 & Pertemuan 3 & & \\
\hline & Pra menulis & & & & & \\
\hline 1 & $\begin{array}{l}\text { Kemampuan siswa menentukan topik } \\
\text { berdasarkan pengalaman }\end{array}$ & 98.04 & 98.04 & 100 & 98.69 & $\begin{array}{l}\text { Sangat } \\
\text { Tinggi }\end{array}$ \\
\hline 2 & $\begin{array}{l}\text { Kemampuan siswa mengumpulkan kata-kata } \\
\text { atau frasa sesuai topik }\end{array}$ & 98.04 & 98.04 & 100 & 98.69 & $\begin{array}{l}\text { Sangat } \\
\text { Tinggi }\end{array}$ \\
\hline & Saat menulis & & & & & \\
\hline 3 & $\begin{array}{l}\text { Kemampuan Siswa mengembangkan } \\
\text { kerangka karangan }\end{array}$ & 92.16 & 88.24 & 92.16 & 90.85 & $\begin{array}{l}\text { Sangat } \\
\text { Tinggi }\end{array}$ \\
\hline 4 & $\begin{array}{l}\text { Kemampuan Siswa menyususn dan mengolah } \\
\text { kata-kata atau frasa menjadi sebuah karangan } \\
\text { Pascamenulis }\end{array}$ & 96.08 & 96.08 & 98.04 & 96.73 & $\begin{array}{l}\text { Sangat } \\
\text { Tinggi }\end{array}$ \\
\hline 5 & $\begin{array}{l}\text { Kemampuan siswa mengoreksi dan } \\
\text { memperbaiki tulisannya dalam pengunaan } \\
\text { ejaan, huruf kapital dan tanda titik }\end{array}$ & 94.12 & 98.04 & 96.08 & 96.08 & $\begin{array}{l}\text { Sangat } \\
\text { Tinggi }\end{array}$ \\
\hline 6 & Kemampuan siswa membaca karangan & 94.12 & 94.12 & 92.16 & 93.47 & $\begin{array}{l}\text { Sangat } \\
\text { Tinggi }\end{array}$ \\
\hline & Rata-rata & 95.42 & 95.42 & 96.41 & 95.75 & $\begin{array}{l}\text { Sangat } \\
\text { Tinggi }\end{array}$ \\
\hline
\end{tabular}

Hasil penelitian pengembangan yang telah dilakukan, akan diuraikan lebih lanjut terutama yang berkaitan dengan validitas, praktikalitas, dan efektivitas bahan ajar yang dikembangkan mengambarkan bahwa isi bahan ajar telah dapat mencapai kompetensi dasar yang diplih. Desain bahan ajar sesuai dengan langkah-langkah menulis deskripsi yang dapat memotivasi siswa dengan tampilann gambar yang menarik pada bahan ajar yang dikembangkan (Idris, Effendi, \& Juita, 2014). Selain itu, penggunaan bahasa dalam bahan ajar menggunakan kalimat yang sederhana dan mudah dipahami oleh peserta didik. Kalimat demi kalimat menggunakan ejaan yang tepat. Praktikalitas dari bahan ajar yang dikembangkan khususnya untuk keterampilan menulis deskripsi berorientasi guided writing sudah bersifat kepraktisan, artinya mudah dalam melaksanakannya, mudah pemeriksaannya, dan dilengkapi dengan petunjuk-petunjuk yang jelas sehingga memudahkan guru dan peserta didik dalam pemakaian perangkat pembelajaran yang digunakan. hal tersebut juga dapat dilihat dari proses pembelajaran menulis dekskripsi berorientasi strategi guided writing dengan membimbing siswa memilih topik, mengembangkan karangan menjadi paragraf, kemudian mengoreksi/merevisi hasil kerja siswa untuk kemudian dibacakan didepan kelas. Selanjutnya, tingkat efektivitas bahan ajar juga diperkuat oleh data pada tahap penyebaran. Keberhasilan pengembangan bahan ajar ini senada dengan hasil penelitian yang dilakukan (Cintiya \& Zufriady, 2019) yang menyimpulkan bahwa strategi guide writing dapat meningkatkan kemampuan menulis siswa khusunya menulis deskripsi dimana bahan ajar yang peneliti kembangkan dirancang sesuai dengan tahapan menulis deskripsi. Hasil analisis data terhadap aktivitas peserta didik selama mengikuti proses pembelajaran dari tiga kali pertemuan diperoleh 
nilai rata-rata $85.88 \%$ dengan kategori sangat baik. Selanjutnya, penilaian proses keterampilan menulis deskripsi yang dilakukan diperoleh nilai rata-rata $95.75 \%$ dengan kategori sangat tinggi.

\section{SIMPULAN DAN REKOMENDASI}

Simpulan penelitian ini yaitu: 1) Telah dihasilkan Pengembangan Bahan Ajar Menulis Deskripsi Menggunakan Strategi Guided Writing berupa RPP dan bahan ajar dengan kategori ratarata sangat valid. Hal ini dapat dilihat berdasarkan hasil validasi dari validator ahli dan praktisi pendidikan yang telah dilaksanakan, baik pada RPP maupun bahan ajar yang dikembangkan. Hasil ini memberi gambaran bahwa bahan ajar yang dikembangkan telah valid dan dapat digunakan dalam proses pembelajaran menulis; 2) Pengamatan keterlaksanaan RPP terhadap guru yang mengajar, respon guru dan peserta didik, observasi, dan wawancara yang telah dilakukan menunjukan gambaran bahwa penggunaan Bahan Ajar Menulis Deskripsi Menggunakan Strategi Guided Writing sangat praktis dan dapat membantu dalam melaksanakan proses pembelajaran menulis deskripsi di kelas; 3) Hasil pengamatan aktivitas dan keterampilan menulis peserta didik memberikan gambaran hasil yang sangat baik, artinya penggunaan Bahan Ajar Menulis Deskripsi Menggunakan Strategi Guided Writing sudah efektif dilaksanakan.

Sebagaimana hasil penelitian ini penulis mengajukan beberapa rekomendasi yang berhubungan dengan pengembangan bahan ajar menulis deskripsi berorientasi guided writing yaitu : 1) guru memahami dengan benar pelaksanaan Strategi guided writing dengan baik agar tujuan pembelajaran dapat tercapai secara maksimal dengan mengunakan bahan ajar yang dikembangkan; 2) untuk peneliti selanjutnya, penelitian ini dapat dijadikan referensi untuk membuat penelitian yang berhubungan dengan strategi guided writing.

\section{DAFTAR PUSTAKA}

Abbas, S. (2006). Pembelajaran Bahasa Indonesia yang Efektif di Sekolah Dasar. Jakarta: Depdiknas.
Arief, D. (2014). The Development Of Narrative Writing Learning Model For Elementary Schools in Padang. Padang.

Arief, D. (2018). Pengembangan Literasi Menulis Prosa. Dengan Mengunakan Guided Writing sebagai upaya pecerdasan karakter menuju generasi Emas Untuk Siswa SD. Retrieved from http://repository.unp.ac.id/27171/

Chandra., Arief, D., Kharisma, A., Habibi, M., \& Suriani, A. (2020). Writing Literacy As An Effort To Build Positive Character Of Elementary School Students. Jurnal PAJAR (Pendidikan Dan Pengajaran), 4(1), 99-110. https://doi.org/://dx.doi.org/10.33578/pjr.v $4 \mathrm{i} 1.7863$

Cintiya, C., \& Zufriady. (2019). Pengaruh Strategi Guided Writing Untuk Meningkatkan Keterampilan Menulis Siswa Kelas V Sd Negeri 187 Pekanbaru. Jurnal PAJAR (Pendidikan Dan Pengajaran), 3(2), 339345.

https://doi.org/http://dx.doi.org/10.33578/p jr.v3i2.6679.

Dahliana, D., Taufina, T., Nasrul, S., \& Sukandar, W. (2019). Pengaruh Teknik Mind Mapping Terhadap Keterampilan Menulis Puisi Siswa Sekolah Dasar. Jinop (Jurnal Inovasi Pembelajaran), 5(1), 17-27. Retrieved

from http://202.52.52.22/Index.Php/Jinop/Articl e/View/6934

Dalman. (2015). Keterampilan Menulis. Jakarta: PT Raja Grafindo Persada.

Fauziah, M., Sulaeman, Y., \& Chandra, C. (2020). Pengembangan LKS Tematik Bahasa Indonesia Kelas V Melalui Kegiatan Lesson Study Di Sekolah Dasar. Jurnal Cakrawala Pendas, 6(1). Retrieved from http://www.jurnal.unma.ac.id/index.php/C P/article/view/1559

Habibi, M., \& Chandra. (2018). Strategi Direct Writing Activity Sebagai Upaya Peningkatan Keterampilan Menulis Deskripsi Bagi Siswa Kelas II SD. Jurnal Inovasi Pendidikan Dan Pembelajaran Sekolah Dasar ISSN, 2(1). 
https://doi.org/https://doi.org/10.24036/jip psd.v2i1.100032

Idris, Y., Effendi, H. T., \& Juita, N. (2014).

Peningkatan Keterampilan Menulis

Karangan Deskripsi Melalui Metode

Discovery Dengan Menggunakan Media

Gambar Mahasiswa Prodi Pendidikan

Bahasa Dan Sastra Indonesia Ta 2011/2012 Universitas Ekasakti Padang. Jurnal Bahasa, Sastra Dan Pembelajaran, 2(3), 15-28.

Taufina. (2015). Keterampilan Berbahasa dan Apresiasi Sastra Indonesia di SD. Padang: Sukabina Press.

Taufina. (2016). Mozaik Keterampilan Berbahasa Di Sekolah Dasar. Bandung: CV. Angkasa.

Yunismar. (2019). Keefektifan Strategi Menulis

Terbimbing untuk Meningkatkan

Keterampilan Mengarang Narasi. Jurnal

PAJAR (Pendidikan Dan Pengajaran), 3(6), 1255-1263. https://doi.org/http://dx.doi.org/10.33578/p jr.v3i6.7887 